\title{
Horticulture Scenario in Tamilnadu: Progress and Constraints
}

\author{
K. Kesavalu \\ Ph.D., Research Scholar, Department of Economics \\ Annamalai University, Chidambaram, Tamil Nadu, India

\section{R. Asokan} \\ Assistant Professor and Research Supervisor, Department of Economics \\ Annamalai University, Chidambaram, Tamil Nadu, India \& \\ Department of Economics, Government Arts College for Women, Salem, Tamil Nadu, India
}

Volume: 9

Issue: 3

Month: June

Year: 2021

P-ISSN: 2319-961X

E-ISSN: 2582-0192

Received: 16.04 .2021

Accepted: 20.05.2021

Published: 01.06.2021

Citation:

Kesavalu, K., et al.

"Horticulture Scenario

in Tamilnadu: Progress

and Constraints." Shanlax

International Journal of

Economics, vol. 9, no. 3, 2021, pp. 29-35.

DOI:

https://doi.org/10.34293/ economics.v9i3.3972

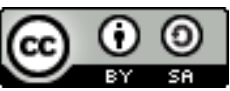

This work is licensed under a Creative Commons Attribution-ShareAlike 4.0 International License

\section{A. Abdul Raheem}

Associate Professor and Co-supervisor, Department of Economics

The New College (A), Chennai, Tamil Nadu, India

\begin{abstract}
Horticulture is now acknowledged as being a vital driver for economic development, poverty reduction and enhanced nutrition for populations in developing countries. Tamil Nadu is one of the foremost horticulture States in India, contributing 7.7 percent to the national horticultural production with 5.7 percent of the national level area. The horticultural crops contain the remarkable potential for export earnings within the State. Cardamom and pepper are important species of Tamil Nadu; Plantation crops of Tamil Nadu are coffee and tea, and that they are traditionally exporting products. Flowers have small areas in Tamil Nadu, but the price of production per hectare is substantial. Palmarosa and indigo are cultivated in negligibly small rooms, mostly for export. Therefore, this paper examines the progress, problems and constraints of the horticulture scenario in Tamilnadu.
\end{abstract}

Keywords: Horticultural crops, Vegetable demand, Landholding, Constraints

\section{Introduction}

Agricultural development has been measured to be a sign of the standard of life at the grassroots level creation it what could also be called peoples sector. An indication of the significance of agriculture during a broader socioeconomic sense, all the three primary objectives of economic development of the country, namely, output growth, price stability and poverty alleviation, are best served by the growth of the agriculture sector. If public investment and market infrastructure in agriculture still be inadequate, there might be significant competitiveness and adequate supply response.

Tamil Nadu is one of the leading horticulture States in India, contributing 7.7 percent to the national horticultural production with 5.7 percent of the national level area. Tamil Nadu has been blessed with diversified agro-climatic conditions, suitable for a good range of horticulture crops like fruits, vegetables, spices, plantation crops, flowers and medicinal plants. An outsized extent of wastelands and underutilized lands are available within the State for horticulture development. The crop diversification technique has been advocated to spice up the production and productivity of horticultural crops. The horticultural crops contain the remarkable potential for export earnings within the State. Cardamom and pepper are essential species of Tamil Nadu; Plantation crops of Tamil Nadu are coffee and tea and traditionally exporting products. 
Flowers have small areas in Tamil Nadu, but the price of production per hectare is substantial. Palmarosa and indigo are cultivated in negligibly small rooms, mostly for export.

Horticulture is now documented as being a vital driver for economic development, poverty reduction and better nutrition for populations in developing countries. More and more achievement stories are receiving recognition, from flowers in Kenya to onion production in Senegal to agro-tourism in Jamaica, to dragon fruit in Vietnam, to high-value vegetables, fruit, medicinal herbs and aromatic plants in India and Egypt. While recognizing barriers to increased exports and access to major international markets do exist, it's also well understood that there are real opportunities for enhanced local, regional, national and intra-continental trade that has the potential to reinforce income to small and medium-sized farmers.

\section{Significance of the Vegetable Industry in Indian Agriculture}

Of the whole land, an operational area of 166 million ha (107 million farms) is out there for agriculture, with $4 \%$ used for vegetables. Smallholders govern both Indian agriculture and vegetable production. Across all production sectors, quite $80 \%$ of farms are being $<2$ ha, and on average, 0.6 ha. Income from attaching crops is inadequate, so farmers add off-farm and non-farm income, and more and more grow high-value crops similar to vegetables. In 2011, vegetable production concerned $15.3 \%$ of farmers, with $<1$ ha producing $34.3 \%$ of national vegetable production from a mean of $20.3 \%$ of their land. Another $26.7 \%$ of vegetables be grown on 1-2 ha from a mean $15.3 \%$ of farm. Across all farm sizes, on average, $14.9 \%$ of farm area was used for vegetables. India is the world's 2nd-largest vegetable producer (11\%) after China \& before Brazil.

\section{Trade}

Vegetable exports quite tripled by volume within the decade from 1995 to 2005 and now stand for about $2.5 \%$ of production. The worth of exports of vegetables and spices approximately tripled from 1999 to 2005. ITC data on export and import value for India 2001-2005 are usually above the info of the FAOSTAT (perhaps ITC is capture more of processed vegetable data) and propose export value has doubled between 2001 and 2005 as imports have remained static, in place of less about $5 \%$ of the worth of exports in 2005. India is finalizing the plan for its 11th 5-year plan, and productivity augment of fifty is proposed for the horticulture sector to give $19 \%$ of agricultural GDP. The implementation of policies, as well as notice on high-value horticulture like vegetables as well as trade and market improvement, could make a payment considerably to several of the plan's socio-economic targets.

\section{Vegetable Demand}

The cuisine of India, and far of South Asia, is well-known for its use of spices during a range of dishes, often described by the term curry. India's long history of vegetarianism may be a well-built power. Meals typically include pulses (e.g., dhal), wheat-based flatbreads or rice, vegetable dishes and accompaniments including curd (yogurt), chutney, and Raita; non-vegetarian meat or fish dishes have Mughal influences. In 2006, an estimated 31\% of Indians were vegetarian (341 million), with rock bottom quantity within the coastal areas of Kerala (2\%), West Bengal (3\%), Andhra Pradesh (4\%), Tamil Nadu (8\%), and Orissa (8\%). The inland states within the north and west have the very best quantity of vegetarian families: Uttar Pradesh (33\%), Madhya Pradesh (35\%), Gujarat (45\%), Punjab (48\%), Haryana (62\%), and Rajasthan (63\%). Even among non-vegetarians, per capita accessibility levels of vegetables and pulses are above accessibility levels in other parts of tropical Asia. Per capita accessibility of vegetables (excluding potato, sweet potato) has been predictable at $183 \mathrm{~g} /$ capita/day and $146 \mathrm{~g} /$ capita/day.

\section{Progress and Constraints \\ (i) Progress and Problems}

Depletion of Water Resources: Tamil Nadu's geographical area consists of 17 river basins, a majority of which are water-stressed. There are 61 main reservoirs, about 40,000 tanks and nearly 3 million wells that extensively use the available surface water (17.5 $\mathrm{BCM}$ ) and groundwater (15.3 $\mathrm{BCM})$. Agriculture is the single major consumer of 
water within the State, using $75 \%$ of the State's water. A recent International Bank for Reconstruction and Development report has exposed that the agriculture sector faces primary constraint thanks to decrepit irrigation infrastructure counting water scarcity mainly thanks to growing demands from industry and domestic users and escalating interstate competition for surface water resources. In some parts of the state, the speed of taking out of groundwater has exceeded recharge rates, most important to falling water tables. Water quality is as well a growing disquiet. Effluents discharged from tanneries and textile industries and heavy use of pesticides and fertilizers have severely impacted surface water quality, soils and groundwater. The government has taken a diversity of progressive actions on water resources and irrigation management, mainly through the Bankassisted Tamil Nadu Water Resources Consolidation Project (WRCP). Tamil Nadu was among the primary states to pass a groundwater bill, Procurement/Right to transparency act and a farmer's management of irrigation systems acts. The State has equipped a planning structure for water resources management and a State Water Policy.

Smaller Size of Holdings: Continually increasing demography force ashore may be a severe cause for concern. The marginal and smallholding represent $89 \%$ of the entire possessions and subsequently, the territory works by $52 \%$ of the whole region. The per capita accessibility of land has been perpetually on the way out and so the accessibility of cultivable land is even worse. The land isn't just an essential factor of creation, yet the important methods for endurance for a more significant part of individuals inside the State of Tamil Nadu. Close by the lessening territory under development, the example of land possession is also antagonistic for the agrarian turn of events. The typical size of holdings has decline from 1.25 ha in 1976-77 to 0.95 ha in 1995-96. The all India figure for the normal region claimed per family is 1.59 ha. This mirrors the power of the populace aground. The portion of complete land work by minor and peripheral ranchers has increased from $42 \%$ to 52 percent during a comparable period. The extension in number and degree of little and minimal ranchers might be a fundamental impediment in advance capital interest in an agricultural area and modernizing horticulture areas. Fracture of land prompts uneconomic land possessions.

Land Debasement and Soil Quality: Land is a pivotal characteristic asset for farming. Land debasement antagonistically influences rural creation. Harvest yields are snared into certain dirt attributes soil supplement content, water-holding limit, natural matter substance, sharpness, topsoil profundity then biomass, etc.

Soil Disintegration: Disintegration is by wind or water. Breakdown causes consumption of ripeness through the expulsion of the valuable and rich dirt. In Tamil, Nadu disintegration is seen in and around 13 lakh ha.

Saltiness and Alkalinity: The unfavorable result of saltiness in the soil is that it obstructs crop development and shows the best approach to diminish crop yield. The unsurprising degree of grounds suffer from salinity and alkalinity is estimated at $2.48 \mathrm{Lakh}$ ha besides 1.23 Lakh ha affected by acidic soils.

Waterlogging and Damp Land: Excess water obstructs plant development by lessening air circulation, which progressively diminishes the water ingestion and supplement take-up by roots. The beachfront locales of Tamil Nadu face hefty harms on account of waterlogging. The order regions in significant water system projects experience water logging issues. In Tamil Nadu, 44,820 ha is assessed as damp grounds; around $14 \%$ of the world in Tamil Nadu is under inadequately depleted soils. Another $16 \%$ is under reasonably very much exhausted to well deplete soils and 15 percent is pretty unnecessarily drained soil.

Decrease in Soil Natural Matter: The dirt wellbeing is disintegrating. The biological matter substance inside the dirt has gone down from $1.20 \%$ in 1971 to $0.68 \%$ in 2002 in Tamil Nadu because of less utilization of natural data sources.

Gullied / Ravine Handles: The chasm is the essential phase of unnecessary land analysis followed by their systems administration which causes the occasion of gorge land. The gorges are a broad arrangement of depths created along invalid as streams and waterway coarse. It's been assessed that Tamil Nadu has 22,550 ha under gullied/gorge lands. 
Badlands are debased terrains that will be brought under vegetative cover.

Tannery and Textile Industrial Pollution: The investigation managed by the Loss of Ecology Authority, Government of India, uncovered that the tannery enterprises have unfavorably influenced 15,164 ha of rural land Vellore locale several,005 ha. in Dindigul area. The Authority had investigated the matter of contamination brought about by the tanneries situated in Vellore, Dindigul, Kancheepuram, Tiruvallur, Erode and Tiruchi regions and granted a total remuneration of Rs 34.73 crore. This sum, to be recuperated from the tanneries, will be utilized for paying compensation to 36,056 people, other than aiding in switching the environmental harm brought about by these tannery enterprises. Tiruppur is quickly developing hosiery 'Mechanical City' in the Coimbatore region of Tamilnadu. It's situated on the bank of the Noyyal River. The profluent released by the material businesses delivered into the Noyyal River contaminates the surface and spring water and harms the farming area. An ecological harm appraisal study directed by Madras School of Economics on rural grounds showed that the whole inundated territory declined from 16,262 ha. To 14,262 ha On the contrary hand, rainfed/non-flooded land expanded from 2108.3 ha. to 2668 ha. The investigation likewise showed that inundated yields like paddy have vanished, prompting a yield loss of Rs. 8.62 lakh in 1994-95 reap costs. The gross yield misfortune for all harvests inside the four towns considered is Rs. 25.23 lakhs.

Mining and Environmental Corruption: It's been unsurprising that 16250 ha are undermining in Tamil Nadu, of which 3285 ha are inside the locale of Salem, followed by 3155 ha in the Cuddalore region. The contrary areas with genuinely significant territory under this sort contain Namakkal, Perambalur, Tirunelveli and Sivagangai. Sand quarrying prompts soil loss, renders squander farmland, obliterates rural exercises and vocations, drains and salinates groundwater quality and shifts stream bearings.

\section{Constraints}

Minimization of land holding, high inconstancy in precipitation dispersion, lacking capital arrangement by the overall population area, declining public venture on farming, declining net region planted, over - abuse of spring water and insufficient stockpiling and post reap offices influence the rural exhibition inside the state. The state upholds seven percent of the nation's populace; however, it's just four percent of the real estate and three percent of water assets of the country. Of the whole gross edited region, just $50 \%$ of the world is watered in Tamil Nadu. Additionally, of the whole region under food grains, just $60 \%$ of the world is flooded. Almost $52 \%$ of the region is under dry cultivating conditions in Tamil Nadu beside stable editing power which is drifting around $120 \%$. Regardless of the above limitations, the State has made gigantic execution inside the creation of yields, which is ascribed primarily to the profitability increment. The strategies of the govt to realize the goal in the Agricultural sector are;

- Adoption of other cropping strategies derived for agro-climatic zone-based cropping pattern evolved by TNAU to boost remunerative crops and to make sure maximum utilization of obtainable land and water getting to increase cropping intensity.

- As a neighborhood of other cropping strategy, cultivation of Jatropha, Sugar beet, and sorgo and contract farming through approved Industrial entrepreneurs for the assembly of ethanol and biodiesel is inspired. These crops are remunerative and may be grown in moderately fertile lands with comparatively less water.

- I am taking up cultivation in a vast tract of wastelands through a massive, comprehensive waste exploitation program.

- Much emphasis on land development integrating watershed development and waste exploitation program.

- Adoption of land development technologies and crop production technologies for land crops to intensify productivity.

- Identification and promotion of relevant technologies to bridge the gap between the potential yield and actual yield of major crops.

- Speedy transfer of technologies to the farming community through ICT (Information and communication technology). 
- Conduct seminars, workshops, and intensive preseason campaigns involving line departments to enthuse and assist farmers in reaping good crops and in urging good profit.

- Efforts to supply technologies and advice on Agriculture, Horticulture soil and moisture conservation, farming, etc., but one roof.

Introduction of Contract farming system for Maize, Oilseeds, Pulses, and Cotton in potential districts with assured repurchase arrangements at a pre-announced price or prevailing market value if it's high. The most objective of the program is to make sure expansion of area under these crops and motive farmers, especially SF / MF farmers, to urge assured remunerative price for the produce.

- Ensure availability of quality seeds on enhanced SRR through Public-Private Partnership.

- Massive adoption of integrated nutrient management and integrated pest management technology with emphasis on eco-friendly agriculture development.

- Much specialize in soil restoration through organic farming approach and to market vermicomposting, compost making through Pleurotus, green manuring, etc.

- Efforts to supply site-specific macro and micronutrient recommendations on the idea of soil test village-wise fertility Index.

- Promotion of micro-irrigation to maximize water use efficiency.

- Empowerment of girls by revitalizing TANWA groups.

- The strategies of the govt to realize the goal in the Horticultural sector are;

- Thrust on high tech horticulture and precision farming with micro-irrigation and fertigation

- Stabilizing the crop area of water-loving crops and expanding the world under land crops with specializing in effective water management and bringing wastelands under horticulture

- Focus on need-based research and effective coordination with the TNAU and other research institutions

Strengthening the assembly system for pedigree planting material (private/ Government)

- Enactment of State nursery regulation act

- to manage and ensure quality standards
- Promotion of Organic farming for the export market

- Building up a public-private partnership

- Effective transfer of technology by tour-cumtraining to farmers

- Linkage with Agro-Processing Industries.

- Post-harvest management and reduction of Post Harvest losses.

- Strengthening the domestic market system with a focus on urban markets also as rural shandies

- Empowerment of farmers with special specialize in farm women

- E-Governance and human resources development through effective training for extension officers.

- Promotion of Agri Export Zones (AEZ) for specified crops.

\section{Conclusion}

Horticulture is the prime engine that provides relatively higher income, employment opportunities in rural areas besides providing nutritional security. The numerous agro-climatic zones of this State are compatible for the cultivation of fruits, vegetables, flowers, spices, plantation crops, medicinal, aromatic crops and other horticultural crops. Tamil Nadu is that the largest producer of flowers in the country. Though the world under horticultural crops is a smaller amount than one-fifth of total cropped area, its share to total agricultural growth is significantly high Importance on the nutritional value of fruits and vegetables is gaining momentum and their consumption increased, thereby raising the demand. Technology break-through in horticultural crops has improved the standard and yield considerably, bringing higher income to the farmers resulting in crop diversification. There has been a considerable increase in area and production under horticultural crops over the years. Focused attention is going to be given to area expansion and the adoption of hightech methodologies in horticultural crops.

\section{References}

Acharya, S.S. "Agricultural Marketing." State of the Indian Farmer: A Millenium Study. Academic Foundation, 2004.

Agarwal, Anil. Homicide by Pesticides. Centre for Science \& Environment, 2000. 
Birthal, Pratap S., and P.K.Joshi. "Institutional Innovations for Improving Smallholder Participation in High-Value Agriculture: A Case of Fruit and Vegetable Growers' Associations in India." Quarterly Journal of International Agriculture, vol. 46, no. 1, 2007, pp. 49-67.

Crucefix, David. Organic Agriculture and Sustainable Rural Livelihoods in Developing Countries. Natural Resources and Ethical Trade Programme, 1998.

De Haen, Hartwig. "Producing and Marketing Quality Organic Products: Opportunities and Challenges." Sixth IFOAM Trade Conference: Quality and Communication for the Organic Market, 1999.

Erappa, S. Contract Farming in Karnataka: A Boon or a Bane?. Institute for Social and Economic Change, 2006.

Gaikwad, V.R. "Application of Science and Technology for Integrated Agricultural and Rural Development: A Farm-Industry Linkage Approach." Agro-Processing: Strategy for Acceleration and Exports, 1989, pp. 11-22.

Jaiswal, Raj, et al. "Overview of Agribusiness Industry in India: Opportunities and Challenges." Indian Journal of Economics and Development, vol. 16, 2020, pp. 136-143.

Johnson, Greg I., et al. The Vegetable Industry in Tropical Asia: India: An Overview of Production and Trade. AVRDC - The World Vegetable Center, 2008.

Joshi, B.D., et al. Working of Regulated Markets in India. Ministry of Food, Agriculture, Community Development and Co-operation, Government of India, 1971.

Joshi, Neha, and Jayant Gautam. Inequalities in Flow of Agriculture Credit: A Macro and Micro Level Analysis. 2014.

Katyaini, Suparana, and Anamika Barua. "Assessment of Interstate Virtual Water Flows Embedded in Agriculture to Mitigate Water Scarcity in India (1996-2014)." Water Resources Research, vol. 53, no. 8, 2017, pp. 7382-7400.

Kumar, Anil, et al. "Makhana: Dry Food and a Potential Aquatic Cash Crop." Innovations in
Food Technology. Edited by Pragya Mishra, et al., Springer, 2020, pp. 73-107.

Lohr, Kerstin, and Christoph Dittrich. Changing Food Purchasing and Consumption Habits among Urban Middle-Classes in Hyderabad. 2007.

Njeri, M.A., and B. Kim. "Review of Smallholder Market Participation in Kenya: Barriers and Determinants." African Journal of Science and Research, vol. 5, no. 3, 2016, pp. 50-56.

Njeri, M.A., and Bryceson Kim. "Review of Market Orientation: Relationship with Business Performance among Small and Medium Enterprises in Kenya." African Journal of Science and Research, vol. 5, no. 4, 2016, pp. 1-8.

Pretty, Jules, et al. "Policy Challenges and Priorities for Internalizing the Externalities of Modern Agriculture." Journal of Environmental Planning and Management, vol. 44, no. 2, 2001, pp. 263-283.

Pretty, Jules. Agri-culture: Reconnecting People, Land, and Nature. Routledge, 2002.

Pretty, Jules N. Regenerating Agriculture: Policies and Practice for Sustainability and SelfReliance. Earthscan Publications, 1995.

Pretty, Jules N. The Living Land: Agriculture, Food and Community Regeneration in Rural Europe. Earthscan Publications, 1998.

Reddy, Y.V. "Indian Agriculture and Reform: Concerns, Issues and Agenda." Indian Journal of Agricultural Marketing, vol. 15, no. 1, 2001, pp. 1-9.

Sattar, Muzammil, et al. "Impact of pH, Nitrogen and Protein Contents in Some Cucurbits on the Population Build-up of Whitefly, Bemisia tabaci (Homoptera: Aleyrodidae)." Pakistan Journal of Zoology, vol. 37, no. 4, 2005, pp. 275-279.

Scialabba, Nadia. "Factors Influencing Organic Agriculture Policies with a Focus on Developing Countries." IFOAM 2000 Scientific Conference, 2000.

Shetty, S.L. "Policy Responses to the Failure of Formal Banking Institutions to Expand Credit Delivery for Agriculture and Non-Farm Informal Sectors: The Ground Reality and 
Tasks Ahead." Monthly Seminar Series on India's Financial Sector. 2006.

Singh, D.V. Production and Marketing of Off-season Vegetables. Mittal Publications, 1990.

Singh, H.S., et al. "Traditional Mango Growers: The Issue of Dwindling Field Technologies." Progressive Horticulture, 2018, pp. 30-40.

Srivastava, U.K., and N.T. Patel. Managing Food Processing Industries in India. (Indepth
Case Studies of Manufacturer Exporters and Analysis). Oxford \& IBH Publishing Co. Pvt. Ltd., 1994.

von Braun, Joachim, et al. Agricultural and Economic Development Strategies and the Transformation of China and India. International Food Policy Research Institute (IFPRI), 2005.

\section{Author Details}

K. Kesavalu, Ph. D., Research Scholar, Department of Economics, Annamalai University, Chidambraam, Tamil Nadu, India

R. Asokan, Assistant Professor and Research Supervisor, Department of Economics, Annamalai University, Chidambram, Tamil Nadu, India, \& Department of Economics, Government Arts College for Women, Salem, Tamil Nadu, India

A. Abdul Raheem, Associate Professor and Co-supervisor, Department of Economics, The New College (A), Chennai, Tamil Nadu, India, Email ID: abdulraheem1967@gmail.com. 